University of Rhode Island

DigitalCommons@URI

The Rhode Island Current Conditions Index

Economics

8-2010

\title{
Rhode Island Current Conditions Index - August 2010
}

Leonard Lardaro

University of Rhode Island, lardaro@uri.edu

Follow this and additional works at: https://digitalcommons.uri.edu/ricci

Part of the Econometrics Commons

Terms of Use

All rights reserved under copyright.

\section{Recommended Citation}

Lardaro, Leonard, "Rhode Island Current Conditions Index - August 2010" (2010). The Rhode Island Current Conditions Index. Paper 11.

https://digitalcommons.uri.edu/ricci/11

This Article is brought to you for free and open access by the Economics at DigitalCommons@URI. It has been accepted for inclusion in The Rhode Island Current Conditions Index by an authorized administrator of DigitalCommons@URI.For more information, please contact digitalcommons-group@uri.edu. 


\section{BURRENT BDNDITIDNS Index

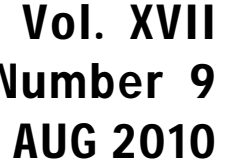

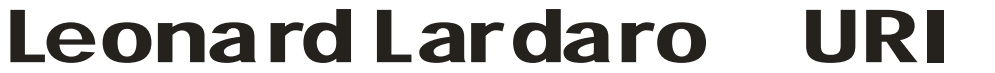

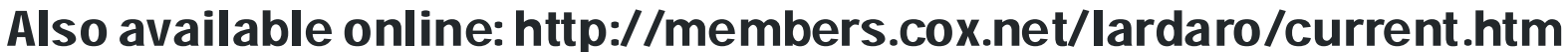

Rhode Island's economic performance has been improving, albeit gradually, over the past several months. Along the way, a "base" of indicators displaying sustained improvement has emerged. Reflecting this, the Current Conditions Index began to move into the expanding range (above 50) with more than half of the indicators improving on several occasions. The first such instance occurred in March, when the $\mathrm{CCl}$ value reached 58. This was not sustained, however, as the next two months saw the $\mathrm{CCl}$ return to its "neutral" value of 50 . Clearly, though, Rhode Island's economy was shifting gear.

August marked the third consecutive month for which the $\mathrm{CCl}$ value has now reached a value of 58 , an expansion value, as seven of twelve indicators improved. To put this into perspective, the last time the $\mathrm{CCl}$ registered three consecutive expansion values was at the end of 2006. Clearly, Rhode Island's economic performance has come a very long way from the depths it experienced in 2008. At this point I feel reasonably confident in stating that I believe Rhode I sland is now in the earliest stages of an economic recovery. The potential downside to this assessment is the pace of national economic activity. But the national "growth blip" appears to have passed (for now), which adds to my confidence in making the recovery call for Rhode Island.

August's economic data were somewhat mixed. On a monthly basis, nine of the twelve $\mathrm{CCl}$ indicators either improved or

\begin{tabular}{|l|r|}
\hline \multicolumn{2}{|c|}{ CCI Indicators - \% Change } \\
\hline Government Employment & -0.5 \\
\hline US Consumer Sentiment & 4.6 Y \\
\hline Single-Unit Permits & -9.5 \\
\hline Retail Sales & 4.4 Y \\
\hline Employment Services J obs & -9.4 \\
\hline Priv. Serv-Prod Employment & -0.4 \\
\hline Total Manufacturing Hours & 1.3 Y \\
\hline Manufacturing Wage & 4.9 Y \\
\hline Labor Force & 0.7 Y \\
\hline Benefit Exhaustions & -33.1 Y \\
\hline New Claims & -2.9 Y \\
\hline Unemployment Rate (change) & 0.1 \\
\hline \multicolumn{2}{|c|}{ Y = I mproved Value } \\
\hline
\end{tabular}

were close to improving. Retail Sales, a critical part of the ongoing base of improving indicators that has formed, sustained its recent momentum, rising for the seventh consecutive month (by $4.4 \%$ ), fueled by improving US Consumer Sentiment $(+4.6 \%)$, which registered its seventeenth consecutive year-over-year improvement. Rhode Island's manufacturing rebound also continued in August, as Total Manufacturing Hours rose again $(+1.3 \%)$, powered by a sharp 1.6 hour increase in the length of the workweek, as the Manufacturing Wage rose by an amazing 4.9 percent. Our state's Labor Force rose again, increasing by 0.7 percent compared to a year ago. While our Unemployment Rate fell slightly to 11.8 percent from July's value, this was at least partially the result of a declining Labor Force. Benefit Exhaustions, which reflects long-term unemployment, fell sharply again, dropping by 33.1 percent in August, its sixth consecutive improvement. New Claims, a leading indicator that measures layoffs, fell by 2.9 percent versus last August, further erasing the effects of three prior consecutive increases. While Employment Service Jobs, another leading labor market indicator, fell by 9.4 percent in August, on a monthly basis, this indicator appears to have plateaued since February, more potentially good news.

Private Service-Producing Employment fell again, but by its smallest rate of decline since February of $2008(0.4 \%)$. Single-Unit Permits continued its roller coaster behavior, dropping 9.5 percent compared to a year ago. Finally, Government Employment fell in August, by 0.5 percent, fueled largely by a decrease in local non-education employment and some added declines in the number of Census-related jobs.

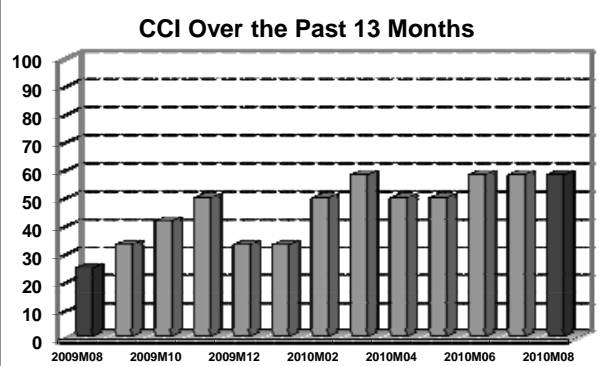

\section{THE BOTTOM LINE}

Based on another month of expanding economic activity, the third consecutive time this has occurred, and the performance of a number of other indicators, I now believe that Rhode Island is in the earliest stages of an economic recovery. I date the beginning of this recovery as June of 2010. Clearly, a base of indicators that has been improving and is likely to continue doing so in the coming months has emerged - at long last!

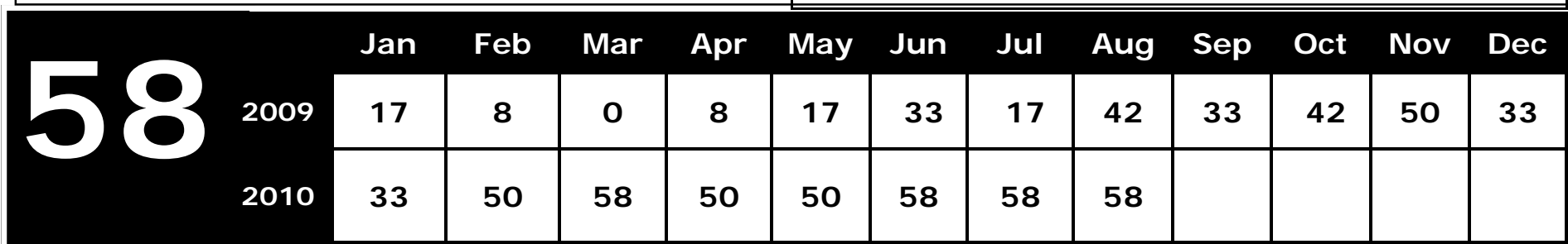

